\title{
Ekstraksi Pemisahan Neodimium dari Samarium, Itrium dan Praseodimium Memakai Tri Butil Fosfat
}

\section{Separation Extraction of Neodymium from Samarium, Yttrium and Praseodymium Using Tri Butyl Phosphate}

\author{
Maria Veronica Purwani*, Suyanti \\ Pusat Sains dan Teknologi Akselerator-BATAN \\ Jl. Babarsari Kotak Pos 6601 ykbb.Yogyakarta 55381 \\ "E-mail: purwanimv@gmail.com
}

Naskah diterima: 9 September 2016, direvisi: 29 Mei 2017, disetujui: 31 Mei 2017

\begin{abstract}
ABSTRAK
Telah dilakukan ekstraksi konsentrat $\mathrm{Nd}(\mathrm{OH})_{3}$ (neodimium hidroksida) yang mengandung $\mathrm{Y}$ (itrium), Sm (samarium) dan $\operatorname{Pr}$ (praseodimium) hasil olah pasir monasit. Tujuan penelitian ini untuk pemisahan Nd dari Y, Pr dan Sm dalam konsentrat $\mathrm{Nd}$. Sebagai fasa air adalah konsentrat $\mathrm{Nd}(\mathrm{OH})_{3}$ dalam $\mathrm{HNO}_{3}$ dan ekstraktan atau fasa organik adalah Tri Butil Fosfat (TBP) dalam kerosen. Parameter yang diteliti adalah $\mathrm{pH}$ umpan, konsentrasi umpan, konsentrasi TBP dalam kerosen, waktu pengadukan dan kecepatan pengadukan. Dari hasil penelitian optimasi proses ekstraksi pemisahan neodimium dari samarium, itrium dan presedimium dalam konsentrat $\mathrm{Nd}(\mathrm{OH})_{3}$ hasil olah pasir monasit dengan ekstraktan TBP, diperoleh kondisi optimum sebagai berikut: $\mathrm{pH}$ umpan = 0,2; konsentrasi umpan $100 \mathrm{gram} / \mathrm{L}$, konsentrasi TBP dalam kerosen $5 \%$, waktu pengadukan 15 menit, kecepatan pengadukan $150 \mathrm{rpm}$. Pada kondisi ini diperoleh FP (faktor pisah) Nd-Y, FP Nd-Pr, FP Nd-Sm masing-masing sebesar 2,242; 4,811; 4,002 dan angka banding distribusi (D) $\mathrm{Nd}=0,236$ dengan efisiensi ekstraksi $\mathrm{Nd}=19,07 \%$.
\end{abstract}

Kata kunci: ekstraksi, TBP, konsentrat Nd

\begin{abstract}
The extraction of $\mathrm{Nd}(\mathrm{OH})_{3}$ (neodymium hydroxide) concentrate containing $Y$ (yttrium), Sm (samarium) and $\operatorname{Pr}$ (praseodymium) as product of monazite processed has been done. The purpose of this study is to determine the separation of $\mathrm{Nd}$ from $\mathrm{Y}, \mathrm{Pr}$ and $\mathrm{Nd} \mathrm{Sm}$ in Nd concentrate. The aqueous phase was concentrated $\mathrm{Nd}(\mathrm{OH})_{3}$ in $\mathrm{HNO}_{3}$ and extractant while organic phase was Tri Butyl Phosphate (TBP) in kerosene. Parameters studied were pH and concentration feed, concentration of TBP in kerosene, extraction time and stirring speed. The result showed that the optimization of separation extraction neodymium from samarium, yttrium and praseodymium in $\mathrm{Nd}(\mathrm{OH})_{3}$ concentrated with TBP, obtained the optimum condition of $\mathrm{pH}=0.2$, concentration of feed $100 \mathrm{~g} / \mathrm{L}$, concentration of TBP in kerosene 5\%, extraction time 15 minutes and stirring speed $150 \mathrm{rpm}$. With the conditions, Separation Factor (SF) obtained for Nd-Y, Nd-Pr, Nd-Sm are 2.242, 4.811, 4.002 respectively, while $D$ and extraction efficiency of Nd are 0.236 and $19.07 \%$.
\end{abstract}

Keywords: extraction, $T B P, N d$ concentrate

\section{PENDAHULUAN}

Neodimium termasuk unsur logam tanah jarang yang keberadaannya berlimpah setelah serium, yang dapat ditemukan dalam mineral monasit. Neodimium adalah sebuah logam kuning keperakan yang berkilauan serta sangat reaktif, merupakan salah satu unsur logam tanah jarang yang dapat ditemukan 
pada peralatan-peralatan rumah seperti televisi berwarna, lampu pijar, dan lampu hemat energi. Campuran logam neodimium, besi, dan boron digunakan dalam pembuatan magnet permanen [1]. Magnet ini adalah bagian dari komponen kendaraan, selain itu digunakan untuk penyimpan data pada komputer dan digunakan pada loudspeaker. Konsentrat Neodimium merupakan salah satu hasil olah pasir monasit yang masih mengandung unsur logam tanah lain seperti Sm, Pr dan Y [2].

Proses ekstraksi pelarut dilakukan untuk memisahkan Nd dari Sm, Pr, dan Y. Pada banyak sistem ekstraksi, ekstraktan dilarutkan dengan suatu pengencer yang tidak saling bereaksi yang disebut diluen. Pemakaian diluen terutama untuk memperbaiki sifat fisika dari fasa organik [3]. Pengencer organik yang sering digunakan adalah kerosen. TBP dapat digunakan untuk mengekstrak logam tanah jarang $(\mathrm{Nd}, \mathrm{La}, \mathrm{Ce}$, Pr, dll.) dalam medium asam nitrat. Pada fasa organik akan terbentuk kompleks $\mathrm{M}\left(\mathrm{NO}_{3}\right)_{3}(\mathrm{TBP})_{3}$ [4].

Sebagai ukuran keberhasilan untuk suatu proses ekstraksi adalah angka banding distribusi (D), efisiensi ekstraksi dan digunakan besaran faktor pisah (FP) yakni perbandingan antara angka banding suatu unsur dengan angka banding unsur yang lainnya. angka banding distribusi (D) adalah perbandingan solut yang dapat larut dalam kedua pelarut. Efektifitas atau efisiensi dalam proses ekstraksi dapat dinyatakan dengan persen solut yang terekstrak [5].

Tri butil fosfat secara umum memiliki rumus kimia $\left(\mathrm{C}_{4} \mathrm{H}_{9}\right)_{3} \mathrm{PO}_{4}$. TBP adalah suatu cairan organik yang pada keadaan murni tidak berbau dan tidak berwarna. Tri butil fosfat merupakan salah satu pelarut organik yang banyak digunakan untuk proses ekstraksi, karena TBP mempunyai kemampuan mengekstrak cukup tinggi dan juga cukup stabil terhadap asam, serta mudah diperoleh [6], [7]. Ekstraksi $\mathrm{La}^{3+}, \mathrm{Ce}^{3+}$ dan $\mathrm{Sm}^{3+}$ menggunakan $\mathrm{CO}_{2}$ superkritis yang berisi bis (2,4,4-trimethylpentyl) asam dithiophosphinic (Cyanex 301) sebagai agen pengkelat dan TBP sebagai co-ekstraktan. Efisiensi pengambilan tertinggi memakai TBP $50 \%$, $\mathrm{La}^{3+}=42,21 \%, \mathrm{Ce}^{3+}=71,12$ dan $\mathrm{Sm}^{3+}=$ 93,50\% [8].

Ekstraksi Pr dan Nd dari larutan klorida menggunakan campuran terner yang mengandung Cyanex 272, Alamine 336 dan TBP. Dibandingkan dengan campuran biner (Cyanex 272 + Alamine 336), campuran terner menunjukkan sinergisme yang luar biasa pada logam dan meningkatkan faktor pemisahan. Faktor sinergis tertinggi diperoleh untuk $\operatorname{Pr}(17,0)$ dan $\mathrm{Nd}(14,6)$ [9]. Kd tertinggi diperoleh untuk $\operatorname{Pr}(17,0)$ dan $\mathrm{Nd}$ $(14,6)$. Nd nitrat yang dimuat dalam autoklaf berhasil diekstraksi dari TBP dan $\mathrm{SC}-\mathrm{CO}_{2}$ pada $15 \mathrm{MPa}, 313 \mathrm{~K}$, efisiensi ekstraksi total yang diperoleh $97 \pm 3 \%$ [10].

Koefisien transfer massa ekstraksi neodymium oksida $\left(\mathrm{Nd}_{2} \mathrm{O}_{3}\right)$ ditentukan dengan menggunakan ligan dibantu karbon dioksida superkritis $\left(\mathrm{SC} \mathrm{CO}_{2}\right)$ [11]. Ligan campuran yang mengandung thenoyl trifluoroacetone (TTA) dan tri-butylphosphate (TBP), $35 \mathrm{MPa}$ dan $60^{\circ}$ C. $\mathrm{TBP}-\mathrm{HNO}_{3}$ digunakan untuk ekstraksi $\mathrm{Nd}_{2} \mathrm{O}_{3}$ dalam SC$\mathrm{CO}_{2}$ [12]. Efek suhu dan tekanan mengindikasikan bahwa proses kinetik ekstraksi reaktif dikontrol oleh reaksi kimia.

Ekstraksi Th dan LTJ dalam media asam nitrat, asam klorida dan asam sulfat dilakukan dengan ekstraktan Cyanex 923, TBP dan DEHPA [13]. Ekstraksi Th dalam medium nitrat lebih efisien dan lebih selektif. Efisiensi tertinggi untuk Th pada konsentrasi $\mathrm{HNO}_{3}=7$ 
mol/L, diperoleh efisiensi ekstraksi hampir $100 \%, \mathrm{Sm}, \mathrm{Nd}, \mathrm{Pr}$ dan La di bawah $5 \%$.

Unsur-unsur dengan valensi tiga tidak terekstrak dengan cepat oleh TBP dalam larutan asam nitrat namun seluruh unsur lantanida yang bervalensi tiga dapat terekstrak dengan TBP walaupun hanya sedikit [14]. Reaksi kimia yang terjadi antara logam tanah jarang dengan TBP adalah sebagai berikut [14]:

$\mathrm{M}^{3+}+3 \mathrm{NO}_{3}{ }^{-}+3 \mathrm{TBP} \rightarrow \mathrm{M}\left(\mathrm{NO}_{3}\right)_{3} .3 \mathrm{TBP}$

Reaksi $\mathrm{Nd}\left(\mathrm{NO}_{3}\right)_{3}$ dengan $\mathrm{TBP}$ sebagai berikut [12]:

$\mathrm{Nd}\left(\mathrm{NO}_{3}\right)_{3}+4 \mathrm{TBP} \rightarrow \mathrm{Nd}\left(\mathrm{NO}_{3}\right)_{3}(\mathrm{TBP})_{4}$

Pada banyak sistem ekstraksi, ekstraktan dilarutkan dengan suatu pengencer yang tidak saling bereaksi yang disebut diluen. Pemakaian diluen terutama untuk memperbaiki sifat fisika dari fasa organik. Pengencer organik yang sering digunakan adalah kerosin.

Tujuan dari penelitian ini adalah untuk mengetahui besarnya angka banding distribusi (D), faktor pisah (FP) dan efisiensi ekstraksi (E).

\section{METODOLOGI}

\section{Alat dan Bahan}

Peralatan yang digunakan antara lain Spektrometer pendar sinar X (Ortec 7010), pengaduk dan pemanas magnetik (Ika ( Werke), timbangan (Sartorius 2464), Gelas kimia berbagai ukuran, labu ukur berbagai ukuran, botol semprot, pipet volume, propipet, botol kecil ukuran $10 \mathrm{~mL}$ Vial, Spex film. Bahan yang digunakan adalah konsentrat $\mathrm{Nd}(\mathrm{OH})_{3}$ hasil olah pasir monasit dengan komposisisi: $\mathrm{Y}(\mathrm{OH})_{3}=10,21 \%$, $\mathrm{Ce}(\mathrm{OH})_{3}=0,30 \%, \quad \operatorname{Pr}(\mathrm{OH})_{3}=1,53 \%$, $\mathrm{Nd}(\mathrm{OH})_{3}=48,49 \%, \mathrm{Sm}(\mathrm{OH})_{3}=28,32 \%$ dan $\mathrm{H}_{2} \mathrm{O}=5,00 \%$. Larutan $\mathrm{HNO}_{3}$ teknis, larutan
TBP, larutan kerosen, akuades, bahan LTJ murni untuk standar analisis.

\section{Cara Kerja}

Variasi pH ekstraksi

Pembuatan larutan TBP-kerosen 15\% sebanyak $100 \mathrm{ml}$. Pembuatan larutan umpan dilakukan dengan melarutkan masing-masing 50 gram konsentrat $\mathrm{Nd}(\mathrm{OH})_{3}$ ke dalam 1000 mL larutan $\mathrm{HNO}_{3}$ yang diatur $\mathrm{pH}$ nya $0 ; 0,2$; 0,$4 ; 0,6$ dan 0,8 .

Memasukkan masing-masing $50 \mathrm{~mL}$ larutan umpan dengan berbagai variasi konsentrasi asam. Sebanyak $50 \mathrm{~mL}$ larutan TBP-kerosen ditambahkan ke dalam larutan tersebut, kemudian diaduk dengan pengaduk magnetik selama 15 menit dengan kecepatan $200 \mathrm{rpm}$.

Memisahkan fasa air dengan fasa organik hasil ekstraksi untuk tiap konsentrasi, kemudian dimasukkan ke dalam botol. Mengambil $5 \mathrm{~mL}$ fasa air untuk selanjutnya dianalisis dengan spektrometer pendar sinar $\mathrm{X}$.

\section{Variasi konsentrasi umpan}

Sebanyak 7,5, 10, 15 dan 20 gram konsentrat $\mathrm{Nd}(\mathrm{OH})_{3}$ dilarutkan ke dalam 100 $\mathrm{mL}$ larutan $\mathrm{HNO}_{3}$ yang mempunyai $\mathrm{pH}$ dengan faktor pisah tertinggi pada variasi $\mathrm{pH}$ umpan. Memasukkan masing-masing $50 \mathrm{~mL}$ larutan umpan dengan berbagai variasi konsentrasi umpan ke dalam lima buah gelas kimia $250 \mathrm{~mL}$. Sebanyak $50 \mathrm{~mL}$ larutan TBPkerosen $15 \%$ ditambahkan ke dalam larutan tersebut, kemudian diaduk dengan pengaduk magnetik selama 15 menit dengan kecepatan $150 \mathrm{rpm}$. Umpan yang memiliki faktor pisah tertinggi digunakan untuk penelitian parameter atau variasi konsentrasi TBP. 


\section{Variasi konsentrasi TBP}

Memasukkan masing-masing $50 \mathrm{~mL}$ larutan umpan yang memiliki faktor pisah tertinggi hasil ekstraksi variasi konsentrasi umpan ke dalam lima buah gelas kimia 250 $\mathrm{mL}$. Sebanyak $50 \mathrm{~mL}$ larutan TBP-kerosen dengan berbagai variasi konsentrasi (5\%, $10 \%, 20 \%$, dan 25\%) ditambahkan ditambahkan secara berturut-turut ke dalam masing-masing larutan tersebut, kemudian diaduk dengan pengaduk magnetik selama 15 menit dengan kecepatan $150 \mathrm{rpm}$.

\section{Variasi waktu ekstraksi}

Memasukkan masing-masing $50 \mathrm{~mL}$ larutan umpan dengan kondisi ekstraksi optimal ke dalam lima buah gelas kimia 250 $\mathrm{mL}$. Sebanyak $50 \mathrm{~mL}$ larutan TBP-kerosen dengan kondisi ekstraksi optimal ditambahkan ke dalam masing-masing larutan tersebut, kemudian diaduk dengan pengaduk magnetik selama 5, 25, 35 dan 45 menit dengan kecepatan 200 rpm. Waktu pengadukan yang memiliki faktor pisah tertinggi digunakan untuk variasi kecepatan pengadukan.

\section{Variasi kecepatan pengadukan}

Memasukkan masing-masing $50 \mathrm{~mL}$ larutan umpan dengan kondisi ekstraksi optimal ke dalam lima buah gelas kimia 250 $\mathrm{mL}$. Sebanyak $50 \mathrm{~mL}$ larutan TBP-kerosen dengan kondisi ekstraksi optimal ditambahkan ke dalam masing-masing larutan tersebut, kemudian diaduk dengan pengaduk magnetik dengan waktu pengadukan yang memberikan faktor pisah tertinggi dengan kecepatan 100, 200, 250 dan 300 rpm.

Besaran yang dihitung Angka banding distribusi (D)

$$
\mathrm{D}=\frac{C_{o}}{C_{a}}
$$

dimana $\mathrm{D}=$ angka banding distribusi dan, $\mathrm{C}_{\mathrm{o}}$, adalah konsentrasi solut pada pelarut organik, dan $\mathrm{C}_{\mathrm{a}}$ adalah konsentrasi solut pada pelarut air [8]

Faktor pisah (FP)

$$
\mathrm{FP}=\frac{D_{1}}{D_{2}}
$$

dengan $\mathrm{D}_{1}$ adalah angka banding unsur 1 dan $\mathrm{D}_{2}$ adalah angka banding unsur 2 .

Efektifitas atau efisiensi dalam proses ekstraksi:

$$
\mathrm{E}=\frac{C o}{F} \times 100 \%
$$

dengan $\mathrm{E}$ adalah efisiensi ekstraksi (\%), $\mathrm{C}_{\mathrm{o}}$ adalah konsentrasi solut dalam fasa organik, dan $F$ adalah konsentrasi umpan untuk ekstraksi.

\section{HASIL DAN PEMBAHASAN Variasi pH Umpan}

Pada proses ekstraksi, keasaman fasa air merupakan faktor yang sangat penting. Harga $\mathrm{pH}$ atau - $\log \left(\mathrm{H}^{+}\right)$dapat menunjukkan konsentrasi $\left(\mathrm{H}^{+}\right)$atau dalam hal ini konsentrasi $\mathrm{HNO}_{3}$. Penambahan $\mathrm{HNO}_{3}$ menyebabkan bertambahnya ion $\mathrm{H}^{+}$dan ion $\mathrm{NO}_{3}{ }^{-}$menurut reaksi sebagai berikut [15]:

$\begin{array}{lll}\mathrm{H}^{+}+\mathrm{NO}_{3}^{-} & \rightarrow \mathrm{HNO}_{3(\mathrm{a})} \\ \mathrm{HNO}_{3(\mathrm{a})} & \rightarrow \mathrm{HNO}_{3(\mathrm{o})} \\ \mathrm{Nd}(\mathrm{OH})_{3}+3 \mathrm{HNO}_{3} & \rightarrow \quad \mathrm{Nd}_{\left(\mathrm{NO}_{3}\right)_{3}+\mathrm{H}_{2} \mathrm{O}} \\ \mathrm{HNO}_{3(\mathrm{o})}+\mathrm{TBP}_{(\mathrm{o})} & \rightarrow \mathrm{HNO}_{3} \cdot \mathrm{TBP}_{(\mathrm{o})} \\ \mathrm{Nd}^{3+}+3\left(\mathrm{HNO}_{3} \cdot \mathrm{TBP}\right) & \rightarrow\left(\mathrm{NO}_{3}\right)_{3} \cdot 3 \mathrm{TBP}_{(\mathrm{o})}+3 \mathrm{H}^{+}\end{array}$

Asam nitrat digunakan untuk membentuk kompleks $\left(\mathrm{HNO}_{3}\right.$.TBP $)$ yang berfungsi sebagai perantara pembentuk kompleks dengan logam (solut). Konsentrasi $\mathrm{HNO}_{3}$ yang berlebihan dapat menyebabkan terdegradasinya TBP menjadi Mono Butil Fosfat (MBP) dan Di Butil Fosfat (DBP) [16]. DBP dan MBP tersebut larut dalam fasa organik, DBP dapat membentuk senyawa kompleks dengan logam dengan ikatan yang 
kuat sehingga sulit diektraksi kembali. Semakin rendah $\mathrm{pH}$, konsentrasi $\mathrm{HNO}_{3}$ semakin besar dengan demikian TBP akan mudah terdegradasi. Sehingga reaksi antara TBP dengan Y, Pr, Nd dan Sm akan terganggu sehingga baik $\mathrm{D}$ maupun efisiensi ekstraksi menjadi rendah. Tetapi kalau $\mathrm{pH}$ semakin tinggi atau konsentrasi $\mathrm{HNO}_{3}$ semakin rendah juga akan menyebabkan reaksi semakin rendah.

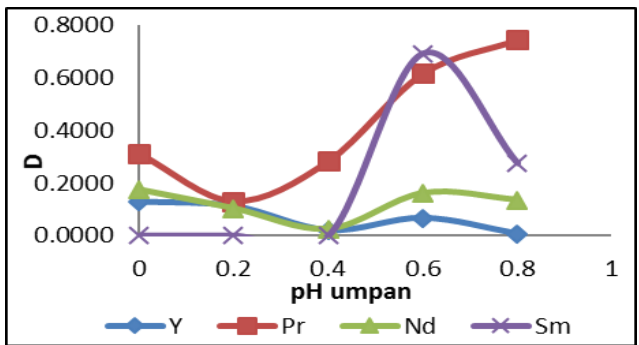

Gambar 1. Kurva hubungan pH umpan dengan D.

Gambar 1 menyajikan hubungan antara $\mathrm{pH}$ atau keasaman umpan dengan D. Angka banding distribusi paling tinggi hanya di bawah 1, menunjukkan bahwa ekstraksi atau perpindahan solut ke fasa organik tidak maksimal.

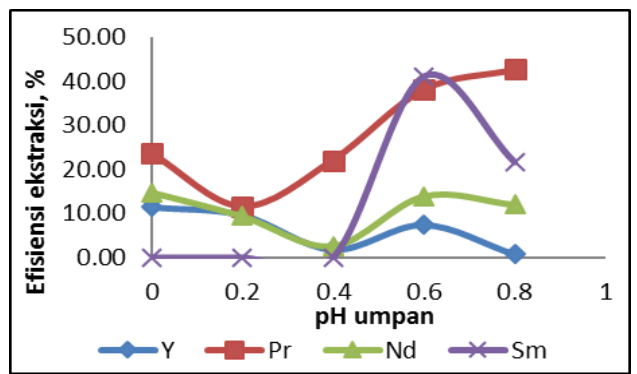

Gambar 2. Kurva hubungan $\mathrm{pH}$ umpan dengan efisiensi ekstraksi.

Ekstraksi atau perpindahan solut ke fasa organik yang tidak maksimal ini dapat dilihat juga pada Gambar 2 yang menyajikan hubungan antara $\mathrm{pH}$ atau keasaman umpan dengan efisiensi ektraksi. Efisiensi ekstraksi tertinggi dibawah 50\%.

Pada Tabel 1 menyajikan pengaruh $\mathrm{pH}$ umpan terhadap FP. Berdasarkan Tabel 1, Gambar 1, dan Gambar 2 , dapat dilihat bahwa harga D Y, Pr, Nd dan $\mathrm{Sm}$ dan efisiensi ekstraksi Y, Pr, Nd dan Sm akan naik seiring bertambahnya $\mathrm{pH}$, kemudian akan turun pada saat $\mathrm{pH} 0,4$. Nilai $\mathrm{D}$ dan efisiensi ekstraksi yang diperoleh dapat dilihat bahwa unsur yang paling mudah diekstraksi adalah Pr, kemudian Nd, Sm, dan Y. Pada pengaruh $\mathrm{pH}$ akan ada kompetisi antara jumlah $\mathrm{HNO}_{3}$ dan kerusakan TBP karena $\mathrm{HNO}_{3}$. Nilai faktor pisah (FP) semakin mendekati 1 semakin tidak terpisah antara $\mathrm{Nd}$ dengan unsur lainnya. Pada variasi $\mathrm{pH}$ umpan dipilih $\mathrm{pH}$ 0,2 dengan efisiensi ekstraksi $\mathrm{Nd}=14,81 \%$, efisiensi ekstraksi $\mathrm{Y}$ $=9,68 \%$, efisiensi ekstraksi $\operatorname{Pr}=11,48 \%$, efisiensi ekstraksi $\mathrm{Sm}=0, \mathrm{D} Y=0,1118, \mathrm{D}$ $\operatorname{Pr}=0,3102, \quad \mathrm{D} \mathrm{Nd}=0,1034, \mathrm{D} \mathrm{Sm}=0$, dengan FP Nd-Y $=0,924, \mathrm{FP}$ Nd-Pr $=0,797$ dan FP Nd-Sm $=\approx \infty$.

Tabel 1. Pengaruh $\mathrm{pH}$ umpan terhadap FP

\begin{tabular}{cccc}
\hline \multirow{2}{*}{$\begin{array}{c}3 \\
\text { Umpan }\end{array}$} & Nd-Y & Nd-Pr & Nd-Sm \\
\cline { 2 - 4 } 0 & 1,353 & 0,560 & $\approx \infty$ \\
0,2 & 0,924 & 0,797 & $\approx \infty$ \\
0,4 & 1,243 & 0,092 & $\approx \infty$ \\
0,6 & 2,386 & 0,261 & 0,233 \\
0,8 & 17,980 & 0,182 & 0,494 \\
\hline
\end{tabular}

(Konsentrasi umpan $50 \mathrm{~g} / \mathrm{L}$, volume $\mathrm{FA}=\mathrm{FO}=50$ $\mathrm{mL}$, konsentrasi TBP-kerosen 15\%, kecepatan pengadukan 150 rpm, waktu 15 menit ).

\section{Variasi Konsentrasi Umpan}

Nilai angka banding (D) dan efisiensi ekstraksi (\%E) dapat dilihat pada Gambar 4 dan Gambar 5, sedangkan faktor pisah (FP) disajikan pada Tabel 2. Salah satu faktor yang sangat berpengaruh terhadap kecepatan perpindahan massa dari fasa air (FA) ke fasa organik (FO) adalah besarnya konsentrasi solut dalam umpan. Hal ini dapat dijelaskan dengan hukum Fick:

$$
\mathrm{J}_{\mathrm{A}, \mathrm{Z}}=-\mathrm{D}_{\mathrm{AB}} \frac{d c_{A}}{d z}
$$


$\mathrm{J}_{\mathrm{A}, \mathrm{Z}}=$ kecepatan transfer massa, $\mathrm{D}_{\mathrm{AB}}=$ difusivitas massa, $\mathrm{c}=$ konsentrasi, $\mathrm{z}=$ lebar lapisan antar fasa.

Dari persamaan tersebut dapat diketahui bahwa variabel konsentrasi berbanding lurus dengan kecepatan transfer massa, sehingga semakin besar konsentrasi akan semakin besar pula kecepatan perpindahan massa. Disamping dengan itu dengan bertambahnya salah satu reaktan, reaksi semakin sempurna. Gambar 4 menunjukkan bahwa D Nd, Y, Pr, dan $\mathrm{Sm}$ cenderung mengalami kenaikan. Hal ini menunjukkan bahwa kemampuan TBP untuk mengekstrak unsur Nd, Y, Pr, dan Sm masih mampu sampai konsentrasi umpan $200 \mathrm{~g} / \mathrm{L}$.

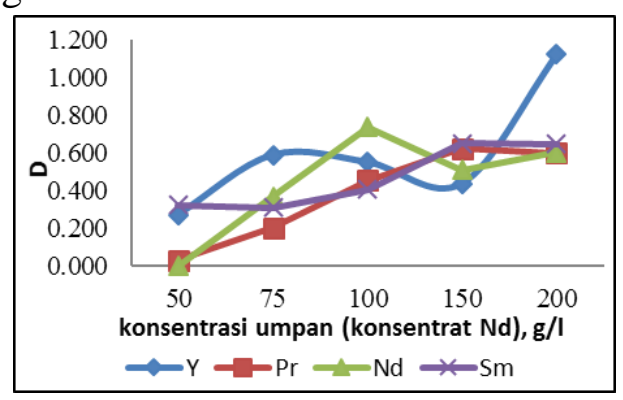

Gambar 3. Kurva hubungan konsentrasi umpan dengan D.

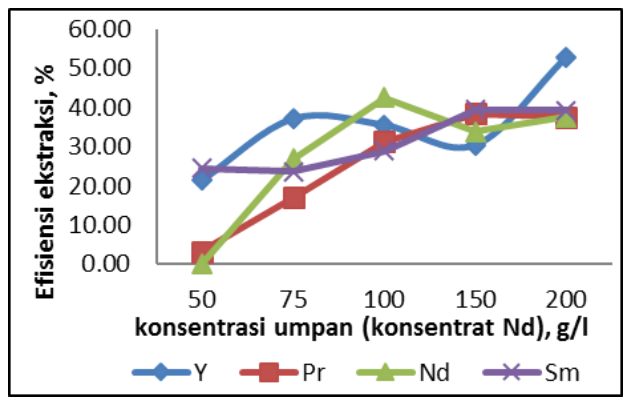

Gambar 4. Kurva hubungan konsentrasi umpan dengan efisiensi ekstraksi.

Pemakaian 15\% TBP-Kerosen mampu mengekstrak sampai mencapai efisiensi ekstraksi hampir 60\%. Hal ini dapat dilihat pada Gambar 5 yaitu hubungan antara konsentrasi umpan dengan efisiensi ekstraksi. Tabel 2 menyajikan pengaruh konsentrasi umpan terhadap FP. Untuk menyimpulkan kondisi optimum konsentrasi umpan pada pemisahan Nd, Y, Pr dan Sm adalah nilai FP tertinggi.

Tabel 2. Pengaruh konsentrasi umpan terhadap FP.

\begin{tabular}{cccc} 
Konsentrasi & \multicolumn{3}{c}{ Faktor Pisah (FP) } \\
\cline { 2 - 4 } Umpan, g/l & $\mathrm{Nd} \mathrm{-} \mathrm{Y}$ & $\mathrm{Nd}-\mathrm{Pr}$ & $\mathrm{Nd}-\mathrm{Sm}$ \\
\hline 50 & 0 & 0 & 0 \\
75 & 0,6221 & 1,7942 & 1,1855 \\
100 & 1,3378 & 1,6235 & 1,8117 \\
150 & 1,1639 & 0,8186 & 0,7835 \\
200 & 0,5371 & 1,0058 & 0,9318
\end{tabular}

$(\mathrm{pH}$ umpan $=0,2$, volume $\mathrm{FA}=\mathrm{FO}=50 \mathrm{~mL}$, konsentrasi TBP-kerosen 15\%, kecepatan pengadukan $150 \mathrm{rpm}$, waktu pengadukan 15 menit).

Hasil optimum dicapai pada konsentrasi umpan $=100 \mathrm{~g} / \mathrm{l}$ dengan efisiensi ekstraksi $\mathrm{Y}$ $=35,53 \%$, efisiensi ekstraksi $\operatorname{Pr}=31,23 \%$, efisiensi ekstraksi $\mathrm{Nd}=42,44 \%$, efisiensi ekstraksi $\mathrm{Sm}=28,92 \%, \mathrm{D} \mathrm{Y}=0,551, \mathrm{D} \mathrm{Pr}=$ $0,454, \mathrm{D} \mathrm{Nd}=0,737, \mathrm{D} \mathrm{Sm}=0,407$. Nilai FP $\mathrm{Nd}-\mathrm{Y}=1,3378, \mathrm{FP}$ Nd-Pr $=1,6235$, dan FP $\mathrm{Nd}-\mathrm{Sm}=1,8117$.

\section{Variasi Konsentrasi TBP}

Nilai angka banding (D) dan efisiensi ekstraksi (\%E) disajikan pada Gambar 5 dan Gambar 6. Pemakaian ekstraktan TBP sangat berpengaruh terhadap pemisahan unsur-unsur didalam umpan yang berupa konsentrat $\mathrm{Nd}(\mathrm{OH})_{3}$. Semakin besar pemakaian konsentrasi ekstraktan maka semakin baik mengekstraksi unsur-unsur dalam umpan, yang ditandai naiknya harga D. Tetapi setelah mencapai konsentrasi tertentu nilai D akan menurun karena pada konsentrasi ekstraktan yang semakin besar perpindahan solut dari fasa air ke fasa organik akan semakin sulit. Hal ini dapat dijelaskan melalui persamaan Stokes-Einstein sebagai berikut [17]

$$
\mathrm{D}_{\mathrm{AB}}=\frac{\kappa T}{6 \pi r \mu_{B}}
$$

$\mathrm{D}_{\mathrm{AB}}=$ difusivitas dari $\mathrm{A}$ di dalam larutan encer dalam $\mathrm{B}, k=$ konstanta Boltzmann, $\mathrm{T}=$ suhu, $\mathrm{R}=$ jari-jari partikel zat terlarut, $\mu_{B}=$ viskositas pelarut 
Persamaan (12) menunjukkan bahwa difusivitas berbanding terbalik dengan viskositas pelarut, sehingga semakin besar viskositas pelarut maka akan semakin mengalami kesulitan untuk berdifusi dari fasa air ke fasa organik, sehingga menurunkan harga D. Semakin besar konsentrasi ekstraktan TBP, viskositas pelarut semakin besar.

Pada Gambar 5 dapat diamati bahwa Nd memiliki D tertinggi pada konsentrasi TBP 15\%. Setelah melewati konsentrasi TBP $15 \%$ harga D cenderung turun karena viskositas ekstraktan sudah semakin tinggi sehingga mengalami kesulitan untuk berdifusi ke fasa organik dan membentuk kompleks dengan Nd. Pada Gambar 6 dapat diamati bahwa Nd memiliki efisiensi ekstraksi tertinggi sebesar pada konsentrasi TBP $15 \%$.

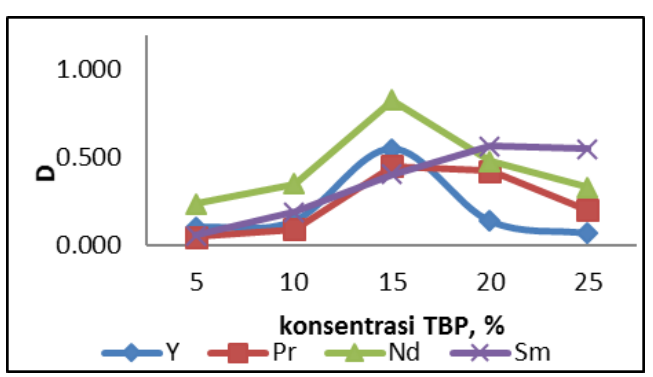

Gambar 5. Kurva hubungan konsentrasi TBP dengan D.

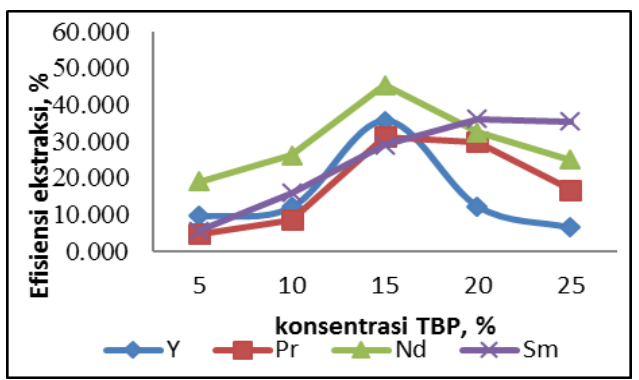

Gambar 6. Kurva hubungan konsentrasi TBP dengan efisiensi ekstraksi.

Neodimium memiliki harga angka banding yang lebih tinggi dibandingkan $\mathrm{Y}$, Pr, dan Sm. Itrium dapat terekstrak dengan baik oleh TBP, dan mempunyai harga D terbesar saat konsentrasi TBP $15 \%$, setelah melewati konsentrasi TBP $15 \%$ harga D menurun. Praseodimium memiliki harga D dan efisiensi tertinggi untuk ekstraktan TBP pada konsentrasi 20\%. Samarium memiliki harga D terbesar pada konsentrasi TBP $20 \%$. Tabel 3 menyajikan pengaruh konsentrasi TBP terhadap FP.

Tabel 3. Pengaruh konsentrasi TBP terhadap FP.

\begin{tabular}{cccc}
\hline TBP & \multicolumn{3}{c}{ Faktor pisah (FP) } \\
\cline { 2 - 4 }$(\%)$ & $\mathrm{Nd}-\mathrm{Y}$ & $\mathrm{Nd}-\mathrm{Pr}$ & $\mathrm{Nd}-\mathrm{Sm}$ \\
\hline 5 & 2,2416 & 4,8110 & 4,0015 \\
10 & 2,5316 & 3,7844 & 1,8624 \\
15 & 1,5000 & 1,8204 & 2,0314 \\
20 & 3,4331 & 1,1319 & 0,8480 \\
25 & 4,7745 & 1,6458 & 0,6060 \\
\hline
\end{tabular}

$\overline{(\mathrm{pH} 0,2 \text {, volume } \mathrm{FA}=\mathrm{FO}=50 \mathrm{~mL} \text {, konsentrasi umpan }}$ $100 \mathrm{~g} / \mathrm{L}$, kecepatan pengadukan $150 \mathrm{rpm}$, waktu pengadukan 15 menit).

Hasil terbaik diperoleh pada konsentrasi ekstraktan TBP 5\%, untuk FP Nd-Y = 2,2416, FP Nd-Pr $=4,8110$. FP Nd-Sm $=4,0015, \quad \mathrm{D}$ $\mathrm{Nd}=0,236$, efisiensi $\mathrm{Nd}=19,07 \%$.

\section{Variasi Waktu Ekstraksi}

Nilai efisiensi ekstraksi (\%E) dan angka banding (D) disajikan pada Gambar 8 dan Gambar 9, faktor pisah (FP) disajikan pada Tabel 4. Perpindahan massa Y, Nd, Pr, dan Sm dari fasa air ke dalam fasa organik ditentukan oleh nilai konstanta difusinya, sehingga perlu dipelajari pengaruh waktu pengadukan. Waktu pengadukan berpengaruh terhadap kenaikan nilai D, waktu kontak antara umpan dengan ekstraktan TBP dalam kerosen akan mempengaruhi distribusi $\mathrm{Y}, \mathrm{Nd}$, Pr, dan Sm ke dalam fasa organik. Semakin lama waktu kontak antara fasa air dengan fasa organik selama proses ekstraksi maka semakin banyak pula jumlah unsur-unsur yang terikat oleh TBP.

Waktu ekstraksi juga terkait dengan jumlah volume yang diaduk, sehingga untuk melakukan variasi waktu pengadukan terhadap volume sebanyak $50 \mathrm{~mL}$ 
diperkirakan cukup memberikan waktu kontak yang efektif, terutama dalam perpindahan solut dari fasa air ke fasa organik.

Waktu ekstraksi diperlukan yang cukup untuk terjadinya reaksi dan terbentuknya hasil reaksi, sehingga reaksi dan hasil reaksi yang diperoleh maksimal. Kecepatan reaksi, berkurangnya reaktan, atau bertambahnya hasil reaksi secara matematis dapat dirumuskan [3]:

$$
[\mathrm{A}]=[\mathrm{A}]_{\mathrm{o}} \cdot \mathrm{e}^{-\mathrm{kt}}
$$

$[\mathrm{A}]=$ konsentrasi $\mathrm{A}$ sesudah bereaksi. $[\mathrm{A}]_{\mathrm{o}}=$ konsentrasi A mula-mula (sebelum bereaksi), $\mathrm{k}=$ konstanta kecepatan reaksi, $\mathrm{t}=$ waktu reaksi.

Bila reaksi yang berlangsung orde satu maka akan diperoleh persamaan (13). Persamaan ini menunjukkan bahwa dalam reaksi orde pertama konsentrasi reaktan akan berkurang secara eksponensial terhadap waktu sedangkan untuk produk akan bertambah.

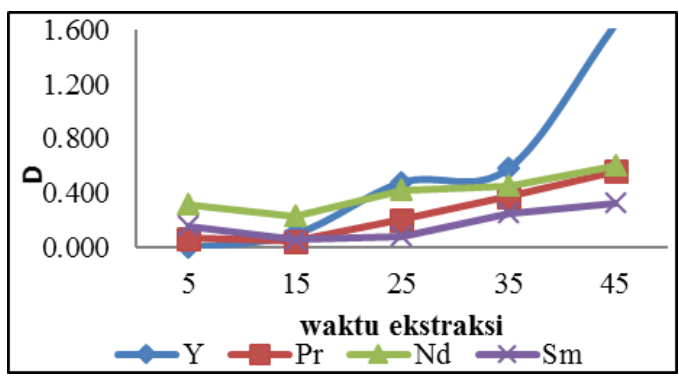

Gambar 8. Kurva hubungan waktu ekstraksi dengan D.

Nilai $\mathrm{D}$ Nd tertinggi sebesar 0,601 dan efisiensi ekstraksi $\mathrm{Nd}$ tertinggi sebesar $37,56 \%$.

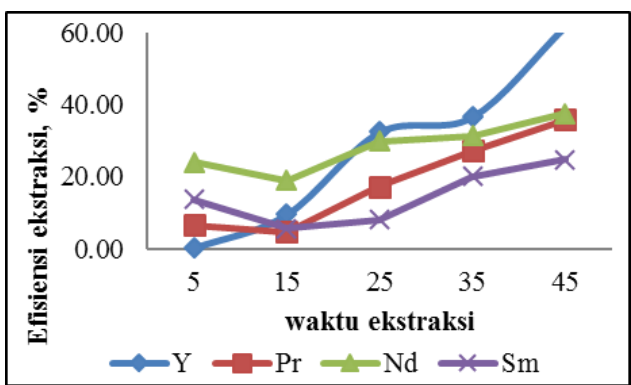

Gambar 9. Kurva hubungan waktu ekstraksi dengan efisiensi ekstraksi.
Waktu ekstraksi yang relatif baik dipilih pada waktu ekstraksi 15 menit. Pemilihan ini berdasarkan bahwa pada waktu tersebut telah memberikan kualitas pemisahan yang cukup baik, hal ini ditunjukkan oleh nilai faktor pisah untuk (Nd-Y) sebesar 2,242, FP Nd - Pr $=4,811$ dan FP Nd $-\mathrm{Sm}=4,002$.

Tabel 4. Pengaruh waktu pengadukan terhadap FP.

\begin{tabular}{cccc}
\hline \multirow{2}{*}{$\begin{array}{c}\text { Waktu } \\
\text { (menit) }\end{array}$} & \multicolumn{3}{c}{ Faktor pisah (FP) } \\
\cline { 2 - 4 } & $\mathrm{Nd}-\mathrm{Y}$ & $\mathrm{Nd}-\mathrm{Pr}$ & $\mathrm{Nd}-\mathrm{Sm}$ \\
\hline 5 & 2,532 & 3,784 & 1,862 \\
15 & 2,242 & 4,811 & 4,002 \\
25 & 0,885 & 2,030 & 4,844 \\
35 & 0,786 & 1,221 & 1,808 \\
45 & 0,369 & 1,073 & 1,827 \\
\hline (pH = 0,2, volume FA=FO= 50 mL, konsentrasi umpan \\
100 g/10 mL, konsentrasi & $\mathrm{TBP}$ & $5 \%$, kecepatan \\
pengadukan 150 rpm)
\end{tabular}

\section{Variasi Kecepatan Pengadukan}

Parameter kecepatan pengadukan penting dilakukan untuk mengetahui kecepatan yang optimum. Dilihat dari sisi perpindahan massa, berdasarkan persamaan (11), dimana $\mathrm{z}=$ lebar lapisan antar fasa adalah jarak atau lebar yang ditempuh oleh unsur atau senyawa yang akan mendifusi dari fasa organik atau sebaliknya. Semakin lebar z difusi semakin lambat, untuk memperpendek $\mathrm{z}$ dilakukan pengadukan yang semakin cepat.

Dilihat dari sisi reaksi kimia, $\mathrm{k}=$ konstanta kecepatan reaksi, yang harganya menurut Arhenius [3],

$$
\mathrm{k}=\mathrm{Ae}^{-\mathrm{E} / \mathrm{RT}}
$$

$\mathrm{A}=$ luas tumbukan, $\mathrm{E}=$ energi aktivasi, $\mathrm{T}=$ suhu, $\mathrm{R}$ $=$ tetapan gas ideal

Semakin cepat pengadukan reaksi akan semakin sempurna karena luas tumbukan juga akan semakin besar.

Proses ekstraksi juga merupakan peristiwa perpindahan massa dari dua cairan yang tidak saling larut, sehingga jika tidak dibantu oleh tenaga dari luar berupa 
pengadukan, maka perpidahan massa dari kedua cairan tersebut akan sangat lambat. Proses pengadukan ini akan membantu pencampuran fasa air dan fasa organik dimana proses pengadukan akan menebarkan solut ke dalam larutan fasa organik sehingga terjadi kontak antar fasa. Peristiwa ini akan meningkatkan perpindahan massa solut dari umpan ke dalam larutan fasa organik.

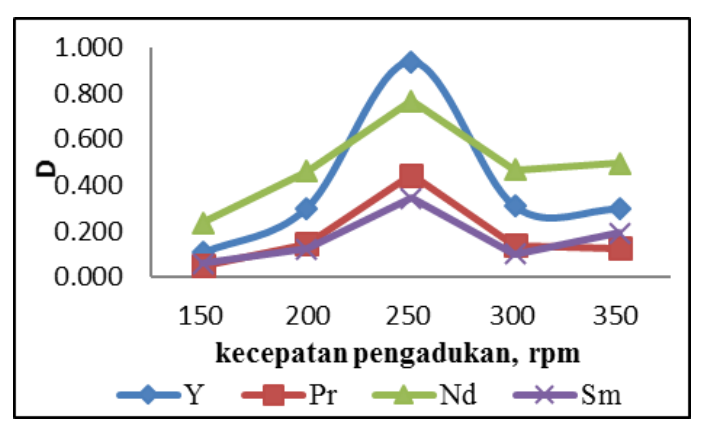

Gambar 9. Kurva hubungan kecepatan pengadukan dengan D.

Gambar 9 dan Gambar 10 menunjukkan bahwa pada kecepatan pengadukan 150-250 rpm, D dan efisiensi ekstraksi mengalami kenaikan. Tetapi setelah kecepatan pengadukan lebih dari $250 \mathrm{rpm}$, D dan efisiensi ekstraksi mengalami penurunan. Pengadukan yang terlalu cepat akan menjadikan pencampuran fasa air dan fasa organik menjadi emulsi yang stabil, sehingga sulit untuk dipisahkan. Gambar 9 menunjukkan adanya kecenderungan kenaikan harga $\mathrm{D}$ dan efisiensi seiring kenaikan kecepatan pengadukan untuk Y. Jadi untuk Y semakin besar kecepatan pengadukan, hasil ekstraksi yang diperoleh juga semakin banyak. Sedangkan untuk $\mathrm{Nd}$ kecepatan pengadukan yang memberikan harga D yang optimum terjadi pada kecepatan $150 \mathrm{rpm}$.

Tabel 5 menyajikan pengaruh kecepatan pengadukan terhadap FP. Kondisi pemisahan yang relatif baik dipilih pada kecepatan pengadukan $150 \mathrm{rpm}$, karena pada kondisi tersebut telah memberikan FP Nd-Y= 2,242, FP Nd - Pr $=4,811, \quad \mathrm{FP} \mathrm{Nd}-\mathrm{Sm}=$ 4,002 dan $\mathrm{D} \mathrm{Nd}=0,236$, efisiensi ekstraksi $\mathrm{Nd}=19,07 \%$. Rangkuman kondisi optimum yang diperoleh disajikan pada Tabel 6 .

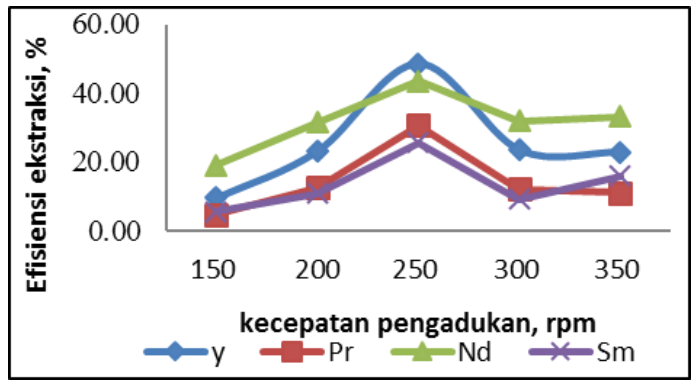

Gambar 10. Kurva hubungan kecepatan pengadukan dengan efisiensi ekstraksi.

Tabel 5. Pengaruh kecepatan pengadukan terhadap FP.

\begin{tabular}{cccc}
\hline Kecepatan & \multicolumn{3}{c}{ Faktor pisah (FP) } \\
\cline { 2 - 4 } Pengadukan, rpm & $\mathrm{Nd}-\mathrm{Y}$ & $\mathrm{Nd}-\mathrm{Pr}$ & $\mathrm{Nd}-\mathrm{Sm}$ \\
\hline 150 & 2,242 & 4,811 & 4,002 \\
200 & 1,533 & 3,214 & 3,781 \\
250 & 0,819 & 1,731 & 2,240 \\
300 & 1,521 & 3,400 & 4,660 \\
350 & 1,673 & 3,969 & 2,591 \\
\hline
\end{tabular}

$(\mathrm{pH}=0,2$, volume $\mathrm{FA}=\mathrm{FO}=50 \mathrm{~mL}$, konsentrasi umpan $100 \mathrm{~g} / 10 \mathrm{~mL}$, konsentrasi TBP $15 \%$, waktu ekstraksi 15 menit).

Tabel 6. Kondisi optimum.

\begin{tabular}{ll}
\hline Parameter & Kondisi \\
\hline pH umpan & 0,2 \\
konsentrasi umpan & 100 gram/L \\
konsentrasi TBP - kerosen & $5 \%$ \\
waktu pengadukan & 15 menit \\
kecepatan pengadukan & $150 \mathrm{rpm}$ \\
\hline
\end{tabular}

\section{KESIMPULAN}

Dari hasil penelitian optimasi proses ekstraksi pemisahan neodimium dari samarium, itrium dan presedimium dalam konsentrat $\mathrm{Nd}(\mathrm{OH})_{3}$ hasil olah pasir monasit dengan ekstraktan TBP, diperoleh kondisi optimum $\mathrm{pH}$ umpan $=0,2$; konsentrasi umpan 100 gram/L, konsentrasi TBP dalam kerosen 5\%, waktu pengadukan 15 menit, kecepatan pengadukan $150 \mathrm{rpm}$. Pada kondisi ini diperoleh FP Nd-Y=2,242, FP Nd-Pr = 
4,811, FP Nd-Sm $=4,002$ dan $\mathrm{D} \mathrm{Nd}=0,236$, efisiensi ekstraksi $\mathrm{Nd}=19,07 \%$.

\section{SARAN}

Untuk meningkatkan D dan efisiensi ekstraksi $\mathrm{Nd}$ perlu dilakukan ekstraksi bertingkat sinambung lawan arah dalam alat pengaduk pengenap. Itrium bisa dipisahkan dahulu dari konsentrat $\mathrm{Nd}$ dengan cara pengendapan.

\section{UCAPAN TERIMA KASIH}

Penelitian ini dibiayai PSTA dan INSINAS tahun 2016. Ucapan terima kasih kami sampaikan untuk Sdr. Suprihati, A.Md. yang telah membantu dalam pelaksanaan penelitian ini.

\section{DAFTAR PUSTAKA}

[1] E. A. Nesbitt and J. H. Wernick, Rare Earth Permanent Magnets. New York: Academic Press Inc, 1973.

[2] Suyanti and M. V. Purwani, "Pembuatan Konsentrat $\mathrm{Nd}$ dari Logam Tanah Jarang Hidroksida (REOH)," in Prosiding PPI, PSTABATAN, 2015.

[3] P. W. Atkins, Kimia Fisika, Jilid 2. Jakarta: Erlangga, 1997.

[4] J. . Preston and A. C. Du Prees, SolventExtraction Processes for Separation of The RareEarth Metals. South Africa: Elsevier Science Publishers B.V., 1992.

[5] D. Haghshenas Fatmehsari, D. Darvishi, S. Etemadi, A. R. Eivazi Hollagh, E. Keshavarz Alamdari, and A. A. Salardini, "Interaction Between TBP and D2EHPA During Zn, Cd, Mn, $\mathrm{Cu}, \mathrm{Co}$ and $\mathrm{Ni}$ Solvent Extraction: A Thermodynamic and Empirical Approach," Hydrometallurgy, vol. 98, no. 1, pp. 143-147, 2009.

[6] S. A. Ansari, N. Kumari, D. R. Raut, P. Kandwal, and P. K. Mohapatra, "Comparative DispersionFree Solvent Extraction of Uranium(VI) and Thorium(IV) by TBP and Dialkyl Amides Using A Hollow Fiber Contactor," Sep. Purif. Technol., vol. 159, pp. 161-168, 2016.

[7] C. Homsirikamol, N. Sunsandee, U. Pancharoen, and K. Nootong, "Synergistic Extraction of Amoxicillin from Aqueous Solution by Using Binary Mixtures of Aliquat 336, D2EHPA and TBP," Sep. Purif. Technol., vol. 162, pp. 30-36, Apr. 2016.
[8] S. Jafari Nejad, H. Abolghasemi, M. A. Moosavian, and M. G. Maragheh, "Fractional Factorial Design for The Optimization of Supercritical Carbon Dioxide Extraction of La3+, $\mathrm{Ce} 3+$ and Sm3+ Ions from A Solid Matrix Using Bis(2,4,4-trimethylpentyl)dithiophosphinic acid+tributylphosphate," Chem. Eng. Res. Des., vol. 89, no. 6, pp. 827-835, 2011.

[9] Y. Liu, H. S. Jeon, and M. S. Lee, "Solvent Extraction of $\mathrm{Pr}$ and $\mathrm{Nd}$ from Chloride Solutions Using Ternary Extractant System of Cyanex 272, Alamine 336 and TBP," J. Ind. Eng. Chem., vol. 31, pp. 74-79, 2015.

[10] K. Sawada, D. Hirabayashi, and Y. Enokida, "Fundamental Studies on Extraction of Actinides from Spent Fuels Using Liquefied Gases Conversion of Copper Into Nitrate with $\mathrm{NO} 2$ and Extraction of $\mathrm{Nd}(\mathrm{III})$ Nitrate by $\mathrm{CO} 2$ with TBP," Prog. Nucl. Energy, vol. 50, no. 2, pp. 483-486, 2008.

[11] T. Vincent, M. Mukhopadhay, and P. K. Wattal, "Supercritical Direct Extraction of Neodymium Using TTA and TBP," Desalination, vol. 232, no. 1-3, pp. 91-101, Nov. 2008.

[12] L. Zhu, W. Duan, J. Xu, and Y. Zhu, "Kinetics of Reactive Extraction of $\mathrm{Nd}$ from $\mathrm{Nd} 2 \mathrm{O} 3$ with TBP-HNO3 Complex in Supercritical Carbon Dioxide," Chinese J. Chem. Eng., vol. 17, no. 2, pp. 214-218, Apr. 2009.

[13] Y. Lu, H. Wei, Z. Zhang, Y. Li, G. Wu, and W. Liao, "Selective Extraction and Separation of Thorium from Rare Earths by A Phosphorodiamidate Extractant," Hydrometallurgy, vol. 163, pp. 192-197, 2016.

[14] W. W. Schulz and J. D. Navratil, Science and Technology of Tributyl Phosphat, Volume 2. Florida: CRC-Press, 1985.

[15] S. I. El Dessouky, Y. A. El-Nadi, I. M. Ahmed, E. A. Saad, and J. A. Daoud, "Solvent Extraction Separation of $\mathrm{Zn}(\mathrm{II}), \mathrm{Fe}(\mathrm{II}), \mathrm{Fe}(\mathrm{III})$ and $\mathrm{Cd}(\mathrm{II})$ Using Tributylphosphate and CYANEX 921 in Kerosene from Chloride Medium," Chem. Eng. Process. Process Intensif., vol. 47, no. 2, pp. 177-183, 2008.

[16] D. R. Prabhu, A. Sengupta, M. S. Murali, and P. N. Pathak, "Role of Diluents in The Comparative Extraction of Th(IV), U(VI) and Other Relevant Metal Ions by DHOA and TBP from Nitric Acid Media and Simulated Wastes: Reprocessing of U-Th Based Fuel in Perspective," Hydrometallurgy, vol. 158, pp. 132-138, 2015.

[17] R. J. Welty, E. C. Wicks, E. R. Wilson, and G. Rorrer, Dasar-Dasar Fenomena Transport (Terjemahan Gunawan Prasetio), 4th ed. Jakarta: Erlangga, 2004. 